\title{
Long-term distribution patterns of mobile estuarine invertebrates (Ctenophora, Cnidaria, Crustacea: Decapoda) in relation to hydrological parameters
}

\author{
Martin J. Attrill ${ }^{1, *}$, R. Myles Thomas ${ }^{2}$ \\ 'Marine Biology \& Ecotoxicology Research Group, Plymouth Environmental Research Centre, University of Plymouth, \\ Drake Circus, Plymouth PL4 8AA, United Kingdom \\ ${ }^{2}$ Environment Agency (Thames Region), Aspen House, Crossbrook St., Waltham Cross, Herts EN8 8HE, United Kingdom
}

\begin{abstract}
Between 1977 and 1992, semi-quantitative samples of macronvertebrates were taken at fortnightly intervals from the Thames Estuary (UK) utilising the cooling water intake screens of West Thurrock power station. Samples were taken for 4 h over low water, the abundances of invertebrates recorded in $30 \mathrm{~min}$ subsamples and related to water volume filtered. Abundances of the major estuarine species have therefore been recorded every 2 wk for a 16 yr period, together with physicochemical parameters such as temperature, salinity and freshwater flow. Annual cycles of distribution were apparent for several species. Carcinus maenas exhibited a regular annual cycle, with a peak in autumn followed by a decrease in numbers over winter, relating to seasonal temperature patterns Conversely, abundance of Crangon crangon was consistently lowest in summer, responding to seasonal changes in salinity, whilst Liocarcinus holsatus, Aurelia aurita and Pleurobrachia pileus were only present in summer samples, with $P$. pileus often in vast numbers $(>100000$ per 500 million $)$. The estuarine prawn Palaemon longirostris showed no obvious sustained annual pattern, but evidence for a longer cycle of distribution was apparent. During 1989-1992 severe droughts in southeast England severely disrupted annual salinity patterns and coincided with a large increase in the Chinese mitten crab Eriocheir sinensis population. This included the first synchronised migration of adults in the UK. Settlement of young crabs during low-flow periods is suggested as an explanation for this population increase.
\end{abstract}

KEY WORDS: Thames Power station Salnity Freshwater flow Crangon. Carcinus. Eriocheir Palaemon Aurelia Pleurobrachia

\section{INTRODUCTION}

Patterns of organism distribution along the length of an estuary are determined primarily by the longitudinal salinity profile (Remane \& Schlieper 1971), a marine organism's penetration up the estuary being dependent on its tolerance to reduced salinities. The ambient salinity at any one point can also vary on a daily basis (due to tidal movement) and on a seasonal basis (due to variations in freshwater input), this variability increasing the stress organisms are subjected to and thus affecting their realized distribution (McLusky

•E-mail: mattrill@plymouth.ac.uk
1971). Much work has been undertaken on the diurnal rhythmic behaviour of estuarine organisms (e.g Janssen \& Kuipers 1980, McGaw \& Naylor 1992, Laprise \& Dodson 1994), but less is known about the effect of the seasonal variation on organism distribution. Long-term data sets with seasonal components tend to concentrate on plankton (Carter \& Dadswell 1983, Castel 1993) and benthic invertebrates (Chapman \& Brinkhurst 1981, Henderson 1984).

The intake of cooling water by power stations provides a convenient and comparatively efficient method of sampling estuarine organisms (Boreman et al. 1981, Summers 1989), the majority of studies focusing on fish communities entrained on intake screens (e.g. Turnpenny 1983, Robin 1988, 1991, Claridge \& Potter 1994). 
Continual sampling from the intakes has provided some long-term, seasonal information on these fish communities (Van den Broek 1979, Andrews 1984, Claridge et al. 1986), together with fewer data on entrained invertebrates (Huddart \& Arthur 1971a, Karas 1992, Bamber \& Henderson 1994). Knowledge remains limited, however, on the consistency of cyclical seasonal patterns in estuarine populations due to the inherent difficulties of compiling such long-term data sets.

Fish populations entrained on power station intake screens were used during the 1960s and 1970s to document the recovery of the polluted Thames Estuary, UK (Huddart \& Arthur 1971b, Wheeler 1979, Andrews \& Rickard 1980), with a diverse fish community being present by the end of the 1970s. Huddart \& Arthur $(1971 \mathrm{a}, \mathrm{c})$ undertook supplementary studies on the brown shrimp Crangon crangon (L.) from power station intake screens, including seasonal abundance patterns and their response to the low oxygen environment present in the Thames at the time. Other studies have provided information on the benthic macrofaunal community (Birtwell \& Arthur 1980, Andrews et al. 1982, Attrill et al, 1996a), with Attrill et al. (1996b) describing the response of upper estuary invertebrate communities to seasonal changes in low freshwater flow. The aims of this paper are therefore to detail the population dynamics of the most abundant invertebrates entrained on power station screens in the Thames Estuary over a period of $16 \mathrm{yr}$ and, where possible, to relate these patterns to changes in the major hydrological parameters.

\section{SITE DESCRIPTION AND SURVEY METHOD}

The Thames Estuary extends $110 \mathrm{~km}$ from Teddington Weir (west London), the limit of tidal influence, through Greater London and out into the southern North Sea (Fig. 1). Approximately 10 million people inhabit the Thames catchment. The pressure of this large metropolitan population has resulted in periods of extremely poor water quality in the Thames Estuary (Wheeler 1979), with large anoxic stretches of the midestuary present during the 1950 s. Recovery of the estuary since the 1960 s has been documented by analysis of the fish communities entrained at power stations, particularly the coal-fired power station at West Thurrock (Fig. 1), situated on the north bank of the estuary $66.5 \mathrm{~km}$ seawards of Teddington Weir (National Grid Reference: TQ 590770 ).

The power station extracts up to 150 million $1 \mathrm{~h}^{-1}$ of water from the Thames estuary for cooling purposes, the intake opening being situated well below the low tide mark. Vertical slats $0.5 \mathrm{~m}$ apart prevent large items of debris entering the system. The final cooling pipes leading to the power station are $2.5 \mathrm{~cm}$ in diameter, so all suspended solid matter and organisms $>1 \mathrm{~cm}$ in size are filtered and removed by 6 rotating band (or Brackett) screens. At the top of the filter, the screen is washed clean by water jets, and the filtered material (including organisms) is flushed via a gutter system to a trash pit and then through a small opening back to the estuary. To collect organisms, square framed nets with mesh size of $1 \mathrm{~mm}$ were fitted to the end of each screen's gutter. Sampling periods started $1 \mathrm{~h}$ before low water and continued for a period of $4 \mathrm{~h}$. The nets were emptied and repositioned every $30 \mathrm{~min}$, the organisms caught in that sample being identified and enumerated. The total catch for the $4 \mathrm{~h}$ period can be summed for temporal comparison.

Seasonal variability in the demand for electricity dictates the amount of water needed to cool the power station's generators, and hence the number of intake pumps in operation (up to 6). Due to this variation, the number of organisms collected is expressed in terms of 500 million 1 to allow comparison between surveys. The number of pumps in operation can also vary during a survey as demand fluctuates, the calculation for number of individuals per 500 million 1 being:

$$
E=\frac{100 A}{\left(P_{1} \times L_{1}\right)+\left(P_{2} \times L_{2}\right)+\ldots+\left(P_{\mathrm{n}} \times L_{\mathrm{n}}\right)}
$$

where $E$ is the expected number of individuals of a species in 500 million $l, A$ the actual number of individuals recorded in the $4 \mathrm{~h}$ sample, $P_{\mathrm{n}}$ is the number of pumps in operation and $L_{\mathrm{n}}$ the length of time (in hours) pumps $P_{\mathrm{n}}$ are in operation.

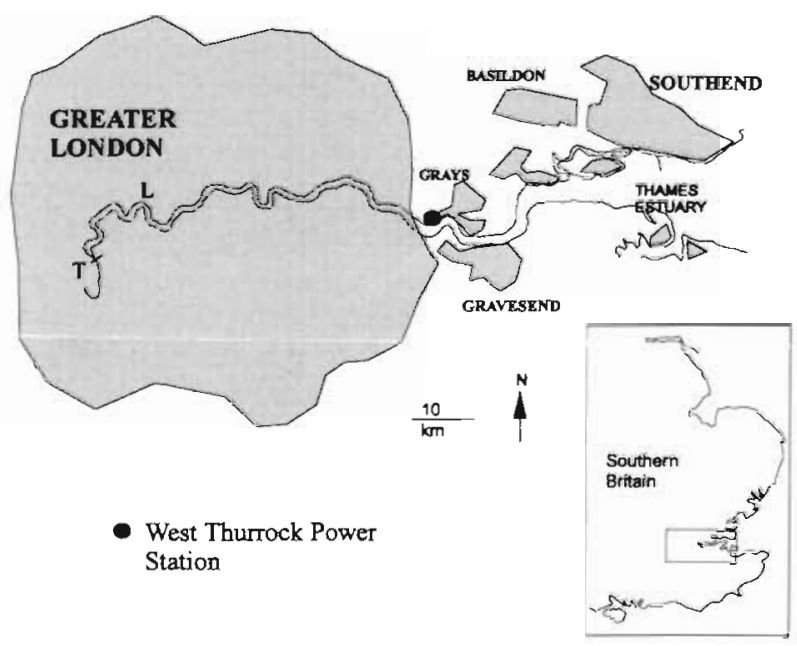

Fig. 1. Map of the Thames Estuary (UK) indicating surrounding metropolitan areas and the position of West Thurrock power station. L: Lots Road power station, Hammersmith: T: Teddington Weir 
Samples of fish and invertebrates were taken by staff from the National Rivers Authority (NRA), and precursory organisations, every 2 wk at spring tide between 1977 and 1992. The power station was closed in 1993

Daily flow rates of freshwater over Teddington Weir were measured by a NRA gauging station. Salinity and temperature measurements were obtained during weekly water analysis runs by the NRA sampling vessel along the length of the estuary, the measurements corresponding to a zone off West Thurrock power station. All salinity measurements were half-tide corrected to allow spatial and temporal comparison.

\section{RESULTS}

\section{Physico-chemical data}

As would be expected for a temperate estuary, there was a strong seasonal pattern in temperature over the 16 yr period surveyed, with summer peaks and winter troughs (Fig. 2). However, there was a distinct increase in the maximum summer temperature between 1977 and 1984, this maximum temperature being maintained above $20^{\circ} \mathrm{C}$ over the ensuing 8 yr. Consistently cold winters occurred between 1982 and 1988, with minimum temperature falling to around or below $5^{\circ} \mathrm{C}$. In 1984 both the highest and lowest water temperatures during the survey were recorded.

Salinity followed a similar, although less predictable, pattern to temperature (Fig. 3), particularly between 1977 and 1988. Annual patterns became far more variable in the ensuing years, with high summer salinities and, at the end of the survey period, no distinguishable winter minimum. Consecutive droughts occurred in southeast England from 1989 to 1992 (Attrill et al. 1996b), thus reducing the freshwater flow over Teddington Weir (Fig. 4) and disrupting the typical salinity patterns within the estuary. High rainfall occurred at the start of 1990, which is reflected in the reduced salinities at West Thurrock, but precipitation across the catchment was minimal after this point, resulting in saline water being present all year off the power station.

\section{Invertebrates}

A wide taxonomic range of invertebrates was recorded in samples from the intake screens at West Thurrock (Appendix 1), but only 3 main groups (ctenophores, scyphozoan cnidarians and decapod crustaceans) were regularly present in large enough numbers to warrant further analysis.

\section{Ctenophora and Cnidaria}

The ctenophore Pleurobrachia pileus (O. F. Müller) was consistently recorded in summer (Fig. 5), in varying numbers ranging from a maximum of 10 (1985) to 100000 (1989). During such blooms $P$. pileus was the dominant organism in catches, resulting in sampling nets rupturing under their weight in 1989. In the majority of years, peak abundances occurred during June or July. The moon jellyfish Aurelia aurita (L.) also formed discrete summer peaks in abundance at West Thurrock, generally being recorded in samples in July/August (Fig. 6). Large numbers of $A$. aurita were a regular occurrence during the first half of the survey, where abundances exceeded 1200 per 500 million l, but between 1985 and 1992 it was comparatively scarce, being absent during 1987.

\section{Crustacea: Decapoda: Natantia}

Six species of natant decapod were recorded in samples from West Thurrock: Crangon crangon, Palaemon longirostris Milne Edwards, Palaemon serratus (Pennant), Pandalus montagui Leach, Palaemon elegans Rathke and Palaemonetes varians (Leach), the latter 2 being rare occurrences, generally as single individuals. $P$. serratus and $P$. montagui were regularly encountered during summer months, but in low numbers. C. crangon was the most consistently abundant species recorded at West Thurrock (Fig. 7), and displayed a distinct cyclical distribution, regularly reaching peak abundances of 10000 to 100000 per 500 million 1 at the end of each year. A dramatic decrease in numbers was evident, generally during May and June, C. crangon being absent from samples in 4 years of the survey at this time. The estuarine prawn $P$. longirostris was also comparatively abundant in the Thames, regularly occurring in significant numbers (peak of 50000 per 500 million l) on the screens at West Thurrock (Fig, 8). There is some evidence that $P$. longirostris exhibits an annual cycle of abundance, with peak numbers in summer and lower numbers during winter months, although this pattern was extremely weak, particularly over the second half of the survey. The population appears to have gone through phases of abundance in this part of the estuary, with larger scale peaks of abundance (e.g. $1982-1985,1990-1992$ ) followed by several years when the species was comparatively scarce (1986-1990).

\section{Crustacea: Decapoda: Brachyura}

Four species of crab were recorded at West Thurrock: Carcinus maenas (L.), Liocarcinus holsatus (Fabricus), 

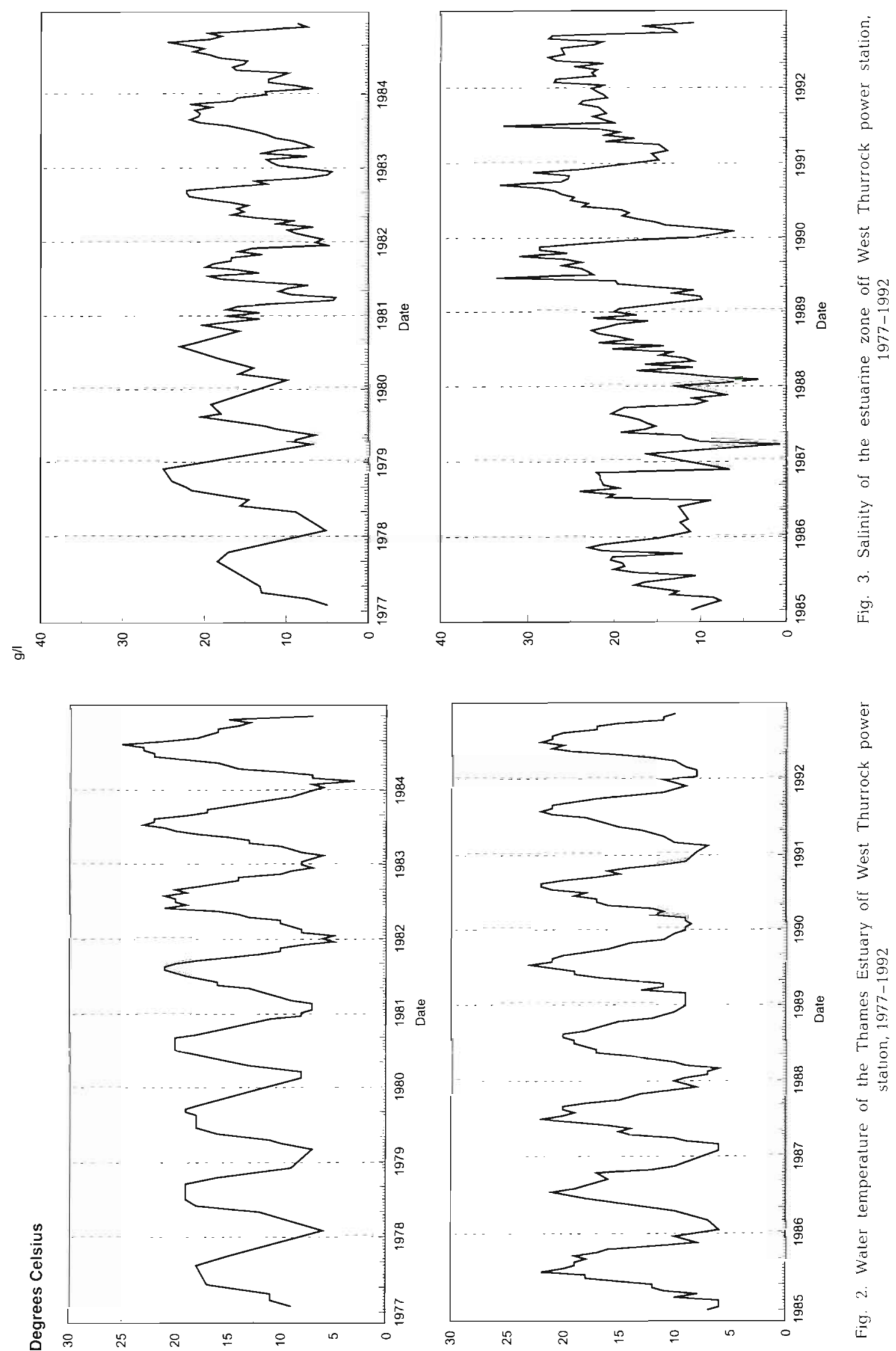

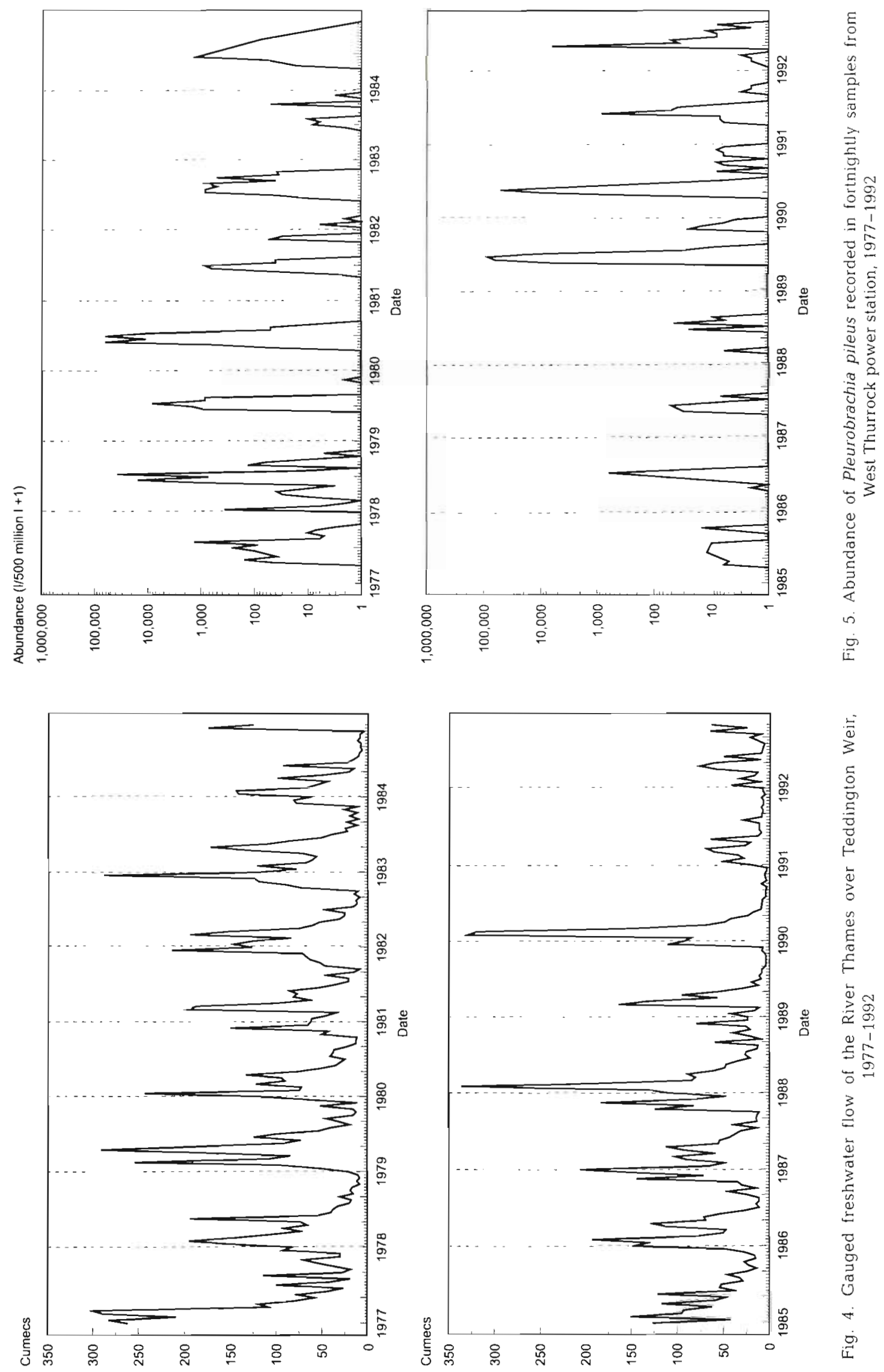

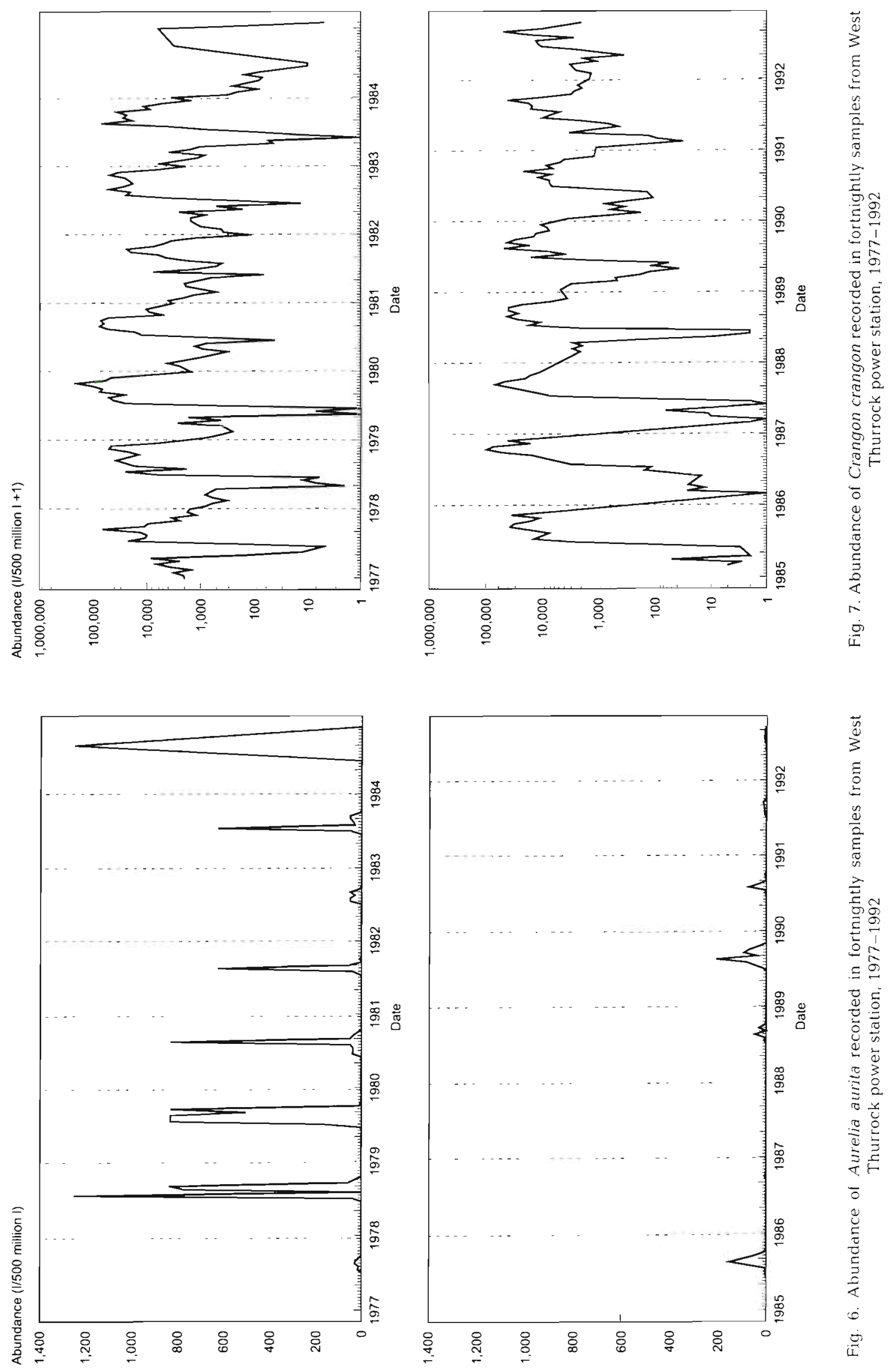
Eriocheir sinensis Milne Edwards and Macropodia rostrata (L.). M. rostrata was only recorded on 1 occasion. probably associated with drifting clumps of the hydroid Sertularia cupressina L. The shore crab C. maenas exhibited a strong annual cycle (Fig 9), with peak abundances being recorded during October or November in the majority of years, the size of this peak varying from $<100$ to 450 per 500 million l. This peak was generally due to a large influx of small crabs $(<3 \mathrm{~cm}$ carapace width) and was followed by a marked decrease in the number of $C$. maenas recorded on the screens, reaching a minimum in January and February. During several years, crabs were absent from February samples. The population demonstrated a steady increase in numbers over the rest of the year. The swimming crab L. holsatus regularly occurred in samples taken during July and August (Fig. 10), the peak abundance for this species ranging from 300 per 500 million l in 1980 to being absent the whole year in 1987

The Chinese mitten crab Eriocheir sinensis has only sporadically been recorded in the UK since 1935 , mostly from the Thames (Ingle 1986), despite being present in vast numbers in European river systems (Panning 1938) following its introduction from the Far East at the start of this century. E. sinensis was occasionally encountered in samples taken at West Thur- rock, but occurrences became more regular after 1988 (Fig. 11). Abundances increased during 1991-1992 culminating in 32 crabs per 500 million 1 being recorded in November 1992. During October 1992. hundreds of crabs were reported in the intake tanks of Lots Road power station (Hammersmith), $45 \mathrm{~km}$ upstream of West Thurrock (Fig. 1). All crabs recorded at West Thurrock in November 1992 were adults, with all females carrying eggs.

\section{DISCUSSION}

The distribution patterns of mobile invertebrates in the Thames Estuary can be divided into 3 categories: summer only, full annual cycles and long-term patterns. Organisms can appear in summer samples either because they are migrating up the estuary following reductions in salinity induced by reduced flow (e.g. Liocarcinus holsatus) or because their population also reaches an annual peak during this season (e.g. Pleurobrachia pileus, Aurelia aurita). L. holsatus generally inhabits coastal areas (Ingle 1983), the population of this swimming crab therefore increasing its spatial range within the Thames estuary during the summer period. This influx of L. holsatus would therefore introduce an
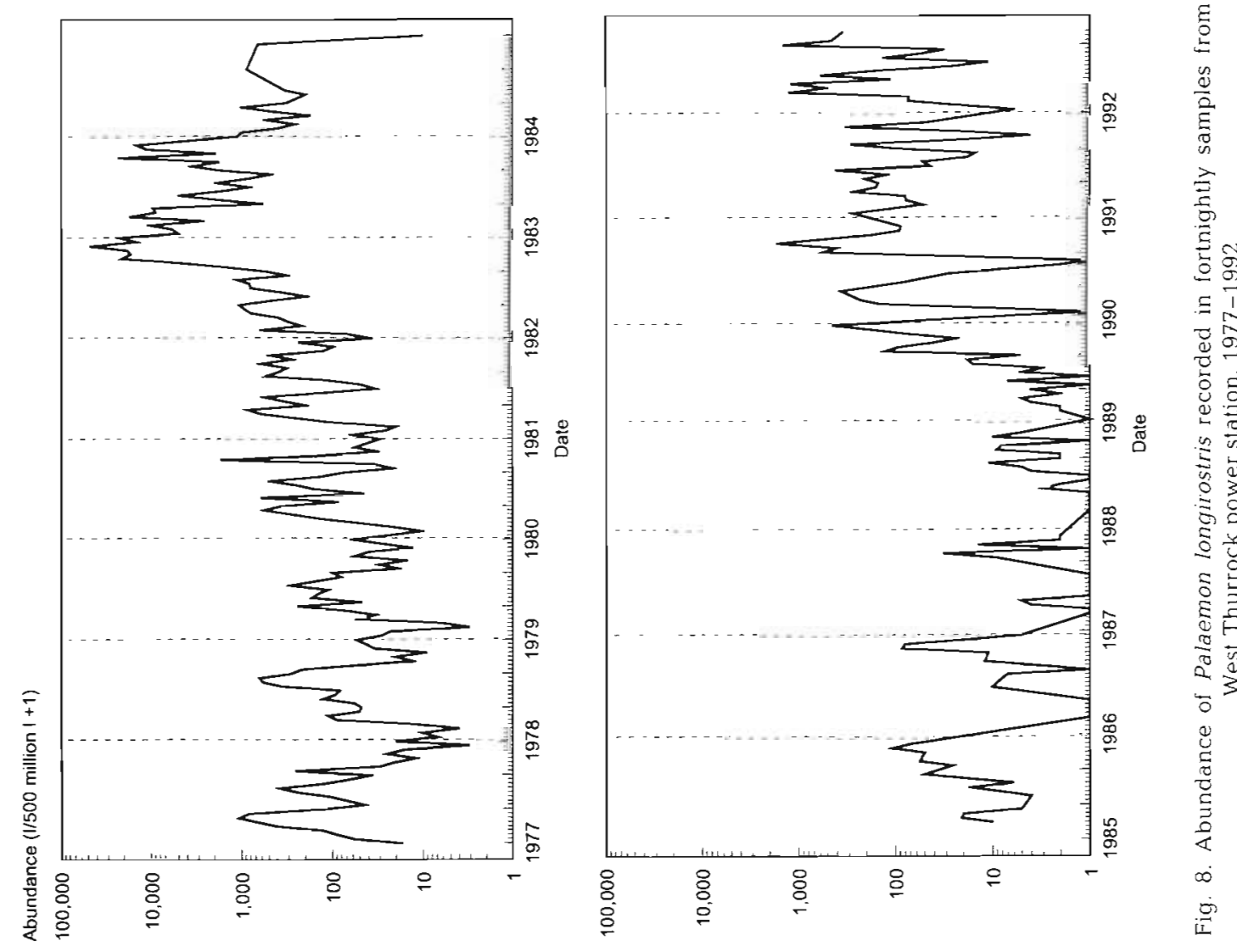

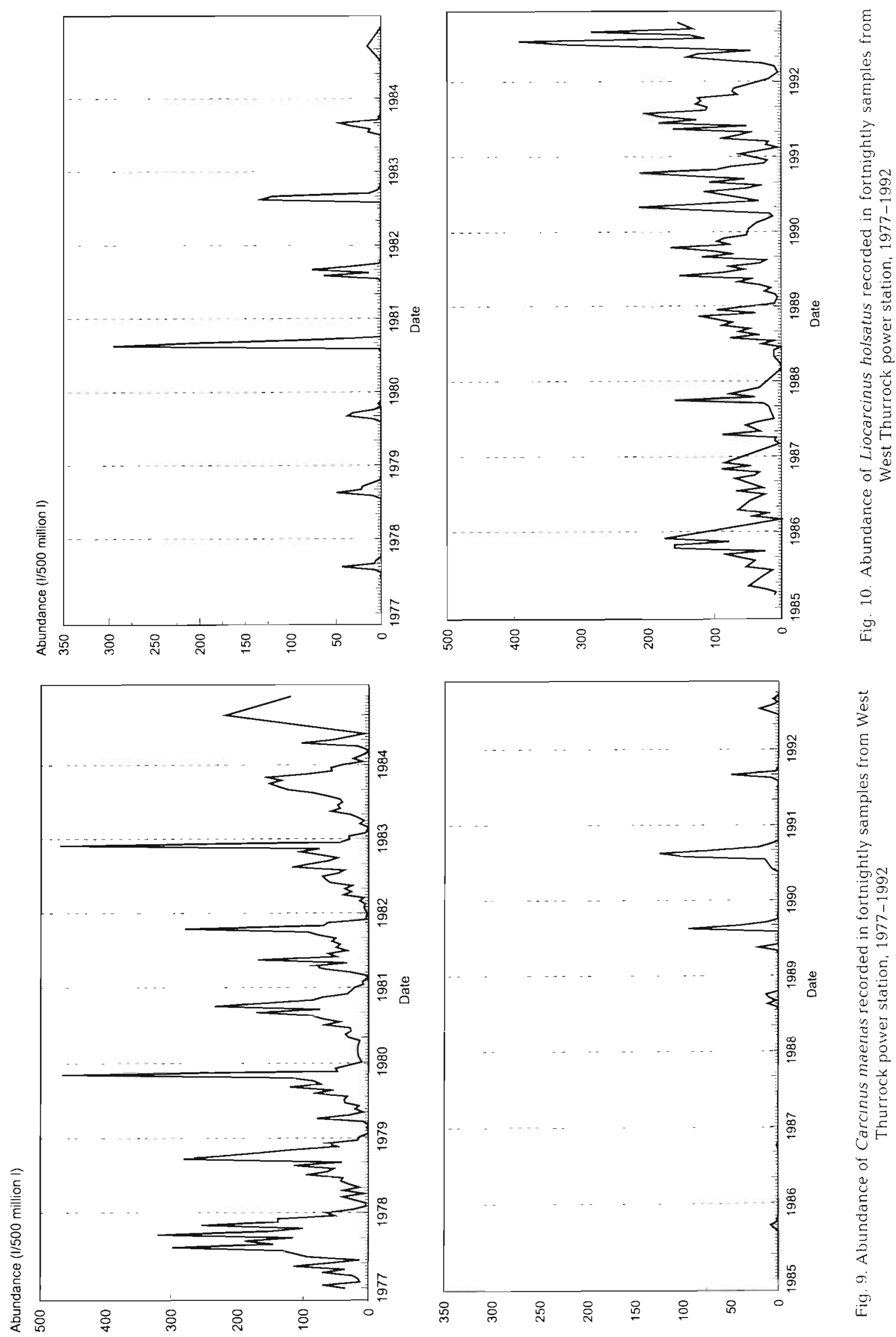
Abundance (//500 million I)

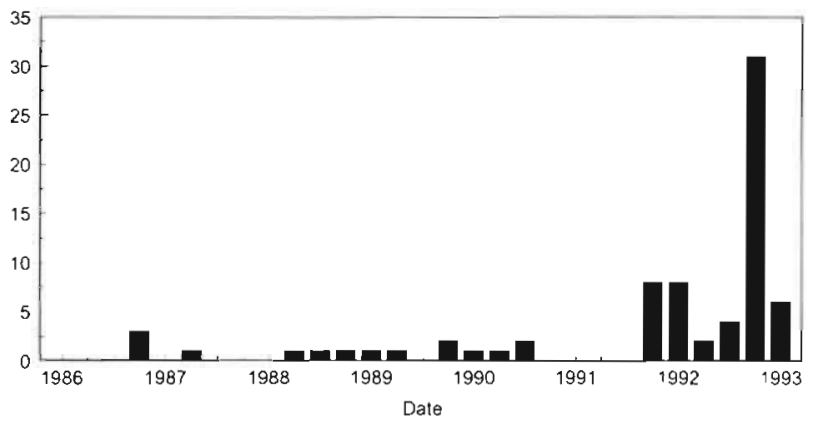

Fig. 11 Abundance of Eriocheir sinensis recorded in fortnightly samples from West Thurrock power station, 1977-1992. Data have been aggregated to quarters: Jan-Mar, Apr-Jun, Jul-Sep, Oct-Dec

additional competitor to resident Carcinus maenas, as their diets and feeding behaviour are similar (Choy 1986 Lee \& Seed 1992). However, the population peak of $C$. maenas at West Thurrock occurs later in the year. Longer-term population trends are evident for $L$. holsatus, with the species being absent, or recorded in very low numbers, between 1984 and 1989, with no associated change in the overall salinity regime for these years.

The gelatinous planktonic species also recorded peaks in abundance during the summer months, Aurelia aurita being present for a much shorter length of time than Pleurobrachia pileus and being much less common over the second half of the survey period. Annual population blooms have been widely recorded for both species (e.g. Möller 1980, Van der Veer \& Sadee 1984, Frank 1986, Schneider \& Behrends 1994) and have been reported to have a significant impact on the zooplankton community (Kuipers et al. 1990. Behrends \& Schneider 1995). However, peak abundances as recorded at West Thurrock (Figs. $5 \& 6$ ) are later in the year for both species than in surrounding North Sea areas. Van der Veer \& Sadee (1984) recorded maximum abundances of $P$. pileus in the Dutch Wadden Sea during May, whilst A. aurita populations generally reach a peak in late spring (Norway: Olesen et al. 1994; Southampton Water: Lucas \& Williams 1994). This delayed peak in the Thames may reflect the period required for the population to move up the estuary.

Several of the crustacean species recorded at West Thurrock are present in the estuary over the majority of the year, but the abundances of 2 species on the intake screens show distinct annual, cyclical fluctuations. The brown shrimp Crangon crangon is perhaps the most common mobile macrofaunal species in large north European estuaries with strong tidal currents (Tiews 1970) and is present in very large numbers in the Thames. Tidal migrations have been recorded for the species (Hartsuyker 1966, Al-Adhub \& Naylor 1975), although Janssen \& Kuipers (1980) found no evi- dence for this in the tidal channels of the Wadden Sea. Seasonal migrations within estuaries have also been recorded (Henderson \& Holmes 1987), peak numbers occurring in the Severn Estuary (UK) between November and January with annual abundance minima during the summer. This pattern is similar to that recorded in the Thames, suggesting that populations migrate seawards during winter to avoid reduced salinities and again later in the year to reproduce (Lloyd \& Yonge 1947. Henderson \& Holmes 1987). At these times C. crangon are entrained on the screens of West Thurrock power station in large numbers, migrating further up the estuary during late spring/summer to exploit the patterns of encroaching salinity. It would therefore appear that this pattern of migration is indicative of estuarine populations of $C$. crangon; the Severn and Thames are considered to hold separate populations of this species (Henderson et al. 1990). In turn, these patterns are distinct from intertidal populations, which reach peak numbers in summer and lowest abundances during winter (Beukema 1992).

The shore crab Carcinus maenas also demonstrates a cyclical pattern of distribution within the Thames, with lowest abundances being recorded at West Thurrock during January-February and peak numbers during October-November. The vast majority of individuals were green type, the orange/red crabs being comparatively intolerant of reduced salinity and thus rarer in estuaries (McGaw \& Naylor 1992). Aagaard et al. (1995) recorded peak numbers of C. maenas during August in a Danish fjord, and associated this with a peak in foraging activity rather than migrations of the population. Lowest abundances were between February and May and related to temperature-dependent activity patterns, the threshold for active foraging being $8^{\circ} \mathrm{C}$ (Naylor 1962, Atkinson \& Parsons 1973). Water temperatures in the Thames Estuary fell below this value for only a short period during January-February in most years (Fig. 2), coincident with minimum abundances of C. maenas, on the intake screens of the power station. It would therefore appear that reduction in catches of C. maenas is due to an inactive population rather than migration of adults. Peak numbers of crabs in the Thames occurred later than those recorded by Aagaard et al. (1995), but this does not necessarily suggest any differences in foraging behaviour. Peaks on the intake screens tended to be due to a large, and short-term, influx of small crabs which masked any other cycles of activity that may have been present.

Two other crustaceans, Palaemon longirostris and Eriocheir sinensis, did not show distinct annual cycles sustained throughout the length of the survey. Between 1977 and 1982, however, peak abundances of $P$. longirostris were recorded during the summer, with corresponding minima in winter. This pattern is in direct 
contrast to other studies on the species in European estuaries (e.g. Marchand \& Alliot 1981, Van den Brink \& Van der Velde 1986, Cartaxana 1994) which have recorded movements of $P$. longirostris in response to changes in salinity. The prawns migrate up to freshwater during periods of reduced river flow and thus should have been absent at the mid-estuary site at West Thurrock during summer if this pattern was repeated in the Thames. During subsequent years this annual pattern was not so evident, the appearance of $P$. longirostris on the screens being sporadic between 1986 and 1990 when the species was absent in samples for periods of time. P. longirostris does, however, show evidence of longer-term population variation, with large numbers of prawns being present in the estuary between 1982-1984 and 1990-1992. During this latter period, drought conditions occurred in the Thames region, with consistent low freshwater flow (Fig. 4). If the population was following the salinity front, it would be expected that the majority of P. Iongirostris would inhabit the upper reaches of the estuary for most of the time, but this was clearly not the case.

Ever since the first Chinese mitten crab was recorded from the Thames Estuary (Harold 1935) records have been few and far between, despite the intensive sampling undertaken during the 1960s and 1970 s to document the clean-up of the estuary. The intensity of sampling continued during the 1980s, with the use of the intake screens at West Thurrock power station, but the status of the mitten crab as an occasional, interesting vagrant continued. The data presented in Fig. 11 demonstrate how this pattern changed during 1991 and 1992, with adult crabs appearing more regularly at West Thurrock culminating in 32 individuals being caught in November 1992. This figure for 1 survey is greater than the combined records of Eriocheir sinensis from the power station for the previous 7 yr, suggesting an aggregation of crabs, perhaps on their spawning migration. This is supported by the fact that all females were ovigerous (so must have spawned in the upper half of the estuary) and particularly by the observation of the large number of crabs at Lots Road power station during October. The estuary at West Thurrock is wider and deeper than at Lots Road, allowing the crabs to disperse. As 30 were still caught on the power station intake screens on the north bank, it would suggest that there were very large numbers of crabs in the estuary at the time. It would appear that this movement of crabs during the end of 1992 was the first large scale breeding migration of $E$. sinensis in the UK.

The question arises as to why, after $60 \mathrm{yr}$ of occasional records from the UK, the Thames population of Eriocheir sinensis has suddenly increased in size. Vast numbers of these crabs are a familiar sight in other northern European countries, but they have never, until now, reached such large abundances in the UK. Ingle (1986) suggested that the UK rivers were much faster flowing than their northern European equivalents, so preventing any large scale settlement and development of mitten crabs. From the evidence presented in this paper it would appear that this hypothesis may be correct. The rise in the number of $E$. sinensis recorded in the Thames Estuary coincides with the overall long-term decrease in freshwater flows following the drought period since 1989 (Fig. 4). It is possible, therefore, that this decrease in flow allowed the establishment of young crabs during 1989, these crabs developing to maturity and so formed the spawning migration witnessed at the end of 1992. At this time the crabs would be approximately 3 to 4 yr old, the age of maturity suggested for the species (Ingle 1986)

Appendix 1. Taxonomic list of invertebrate species recorded from the intake screens at West Thurrock power station. Drifting colonial organisms have been excluded

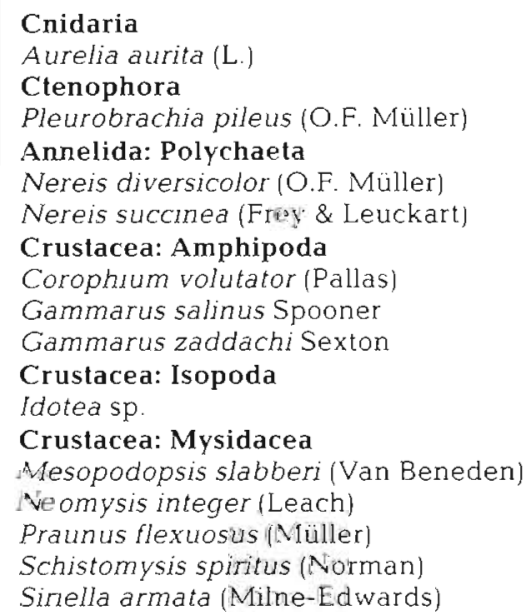

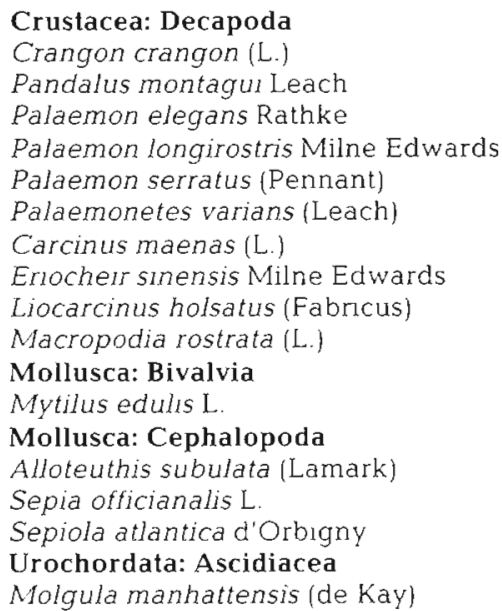


Acknowledgements. We thank the Environment Agency for permission to use data collected during their surveys and the team of people over the past 2 decades who have helped to construct the data set under often unpleasant conditions. The authors stress that the opinions expressed in this paper are their own and not necessarily those of the Environment Agency.

\section{LITERATURE CITED}

Aagaard A, Warman CG, Depledge MH (1995) Tidal and seasonal changes in the temporal and spatial distribution of foraging Carcinus maenas in the weakly tidal littoral zone of Kerteminde Fjord, Denmark. Mar Ecol Prog Ser 122: $165-172$

Al-Adhub AHY, Naylor E (1975) Emergence rhythms and tidal migrations in the brown shrimp Crangon crangon (L.). J Mar Biol Ass UK 55:801-810

Andrews MJ (1984) Thames Estuary: pollution and recovery. In: Sheehan PJ, Miller DR, Butler GC, Bourdeau P (eds) Effects of pollutants at the ecosystem level. John Wiley \& Sons, London, p 195-227

Andrews MJ, Aston KFA, Rickard DG, Steel JEC (1982) Macrofauna of the Thames estuary. Lond Nat 61:30-62

Andrews MJ, Rickard DG (1980) Rehabilitation of the inner Thames Estuary. Mar Pollut Bull 11:327-332

Atkinson RJA, Parsons J (1973) Seasonal patterns of migration and locomotor rhythmicity in populations of Carcinus Neth J Sea Res 7:81-93

Attrill MJ, Ramsay PM, Thomas RM, Trett MW (1996a) An estuarine biodiversity hot-spot. J Mar Biol Ass UK 76:161-175

Attrill MJ, Rundle SD, Thomas RM (1996b) The influence of drought-induced low freshwater flow on an upper-estuarine macroinvertebrate community. Water Res 30:261-268

Bamber RN, Henderson PA (1994) Seasonality of caridean decapod and mysid distributions and movements within the Severn Estuary and Bristol Channel. Biol J Linnean Soc 51:83-91

Behrends G, Schneider G (1995) Impact of Aureha aurita medusae (Cnidaria, Scyphozoa) on the standing stock and community composition of mesozooplankton in the Kiel Bight (western Baltic Sea). Mar Ecol Prog Ser 127:39-45

Beukema JJ (1992) Dynamics of juvenile shrimp Crangon crangon in a tidal flat nursery of the Wadden Sea after mild and cold winters. Mar Ecol Prog Ser 83:157-165

Birtwell IK, Arthur DR (1980) The ecology of tubificids in the Thames Estuary with particular reference to Tubifex costatus (Claparéde). In: Brinkhurst RO, Cook DG (eds) Aquatic oligochaete biology. Plenum Press, New York, p 331-381

Boreman J, Goodyear CP, Christensen SW (1981) An empirical methodology for estimating entrainment losses at power plants sited on estuaries. Trans Am Fish Soc 110:253-260

Cartaxana A (1994) Distribution and migrations of the prawn Palaemon longirostris in the Mira River estuary (SW Portugal). Estuaries 17:685-694

Carter JCH, Dadswell MJ (1983) Seasonal and spatial distribution of planktonic Crustacea in the lower Saint John River, a multibasin estuary in New Brunswick, Canada. Estuaries 6:142-153

Castel J (1993) Long-term distribution of zooplankton in the Gironde Estuary and its relation with river flow and suspended matter. Cah Biol Mar 34:145-163

Chapman PM, Brinkhurst RO (1981) Seasonal changes in interstitial salinities and seasonal movements of subtidal benthic invertebrates in the Fraser River estuary, $\mathrm{BC}$. Estuar Coast Shelf Sci 12:49-66
Choy SC (1986) Natural diet and feeding habits of the crabs Liocarcinus puber and Liocarcinus holsatus (Decapoda, Brachyura, Portunidae). Mar Ecol Prog Ser 31:87-99

Claridge PN, Potter IC (1994) Abundance, seasonality and size of Atlantic salmon smolts entrained on power station intake screens in the Severn estuary. J Mar Bıol Ass UK $74: 527-534$

Claridge PN, Potter IC, Hardisty MW (1986) Seasonal changes in movements, abundance, size composition and diversity of the fish fauna of the Severn Estuary. J Mar Biol Ass UK 66:229-258

Frank KT (1986) Ecological significance of the ctenophore Pleurobrachia pileus off southwestern Nova Scotia. Can J Fish Aquat Sci 43:211-222

Harold $\mathrm{CHH}$ (1935) Thirtieth annual report on the results of the chemical and bacteriological examination of the London waters for the twelve months ended 31 December 1935. Metropolitan Water Board, London

Hartsuyker L (1966) Daily tidal migration of the shrimp Crangon crangon. Neth J Sea Res 3.52-58

Henderson AR (1984) Long term monitoring of the macrobenthos of the upper Clyde Estuary. Water Sci Technol 16 359-373

Henderson PA, Holmes RHA (1987) On the population biology of the common shrimp Crangon crangon (L.) (Crustacea: Caridea) in the Severn Estuary and Bristol Channel J Mar Biol Ass UK 67:825-847

Henderson PA, Seaby R, Marsh SJ (1990) The population zoogeography of the common shrimp (Crangon crangon) in British waters. J Mar Biol Ass UK 70:89-97

Huddart R, Arthur DR (1971a) Shrimps and whitebait in the polluted Thames estuary. Int J Environ Stud 2:21-34

Huddart R, Arthur DR (1971b) Lampreys and teleost fish other than whitebait, in the polluted Thames Estuary. Int $J$ Environ Stud 2:143-152

Huddart R, Arthur DR (1971c) Shrimps in relation to oxygen depletion and its ecological significance in a polluted estuary. Environ Pollut 2:13-35

Ingle RW (1983) Shallow-water crabs. In: Kermack DM Barnes RSK (eds) Synopses of the British fauna, No. 25 Cambridge University Press, Cambridge, p 1-206

Ingle RW (1986) The Chinese mitten crab Eriocheir sinensis H. Milne Edwards - a contentious immigrant. Lond Nat 65:101-105

Janssen GM, Kuipers BR (1980) On tidal migration in the shrimp Crangon crangon. Neth J Sea Res 14:339-348

Karas P (1992) Zooplankton entrainment at Swedish nuclear power plants. Mar Pollut Bull 24:27-32

Kuipers BR, Gaedke U, Enserink L, Witte H (1990) Effect of ctenophore predation on mesozooplankton during a spring outburst of Pleurobrachia pileus. Neth J Sea Res 26:111-124

Laprise R, Dodson JJ (1994) Environmental variability as a factor controlling spatial patterns in distribution and species diversity of zooplankton in the St. Lawrence estuary. Mar Ecol Prog Ser 107:67-81

Lee SY, Seed R (1992) Ecological implications of cheliped size in crabs: some data from Carcinus maenas and Liocarcinus holsatus. Mar Ecol Prog Ser 84:151-160

Lloyd AJ, Yonge CM (1947) The biology of Crangon vulgaris L. in the Bristol Channel and Severn Estuary. J Mar Biol Ass UK 26:626-661

Lucas CH, Williams JA (1994) Population dynamics of the scyphomedusa Aurelia aurita in Southampton Water. J Plankton Res 16:879-895

Marchand J, Alliot A. (1981) Observations sur l'écologie des populations de trois espèces de crustacés, décapodes nageurs en Loire-Atlantique: Palaemonetes varians 
(Leach), Palaemon longirostris H. Milne Edwards et Crangon crangon (Linné). Bull Soc Sci Nat Ouest 3:184-201

McGaw IJ, Naylor E (1992) Distribution and rhythmic locomotor patterns of estuarine and open-shore populations of Carcinus maenas. J Mar Biol Ass UK 72:599-609

McLusky DS (1971) Ecology of estuaries. Heinemann Educational. London

Möller H (1980) Population dynamics of Aurelia aurita medusae in Kiel Bight, Germany (FRG). Mar Biol 60:123-128

Naylor E (1962) Seasonal changes in a population of Carcinus maenas in the littoral zone. J Anim Ecol 31:601-609

Olesen NJ, Frandsen K, Riisgard HU (1994) Population dynamics, growth and energetics of jellyfish Aurelia aurita in a shallow fjord. Mar Ecol Prog Ser 105:9-18

Panning A (1938) The Chinese mitten crab. Smithson Inst, Annu Rep 3508:361-175

Remane A, Schlieper C (1971) Biology of brackish water. Die Binnengewässer. Vol XXV. E Schweizerbartsche Verlagsbuchhandlung, Stuttgart

Robin JP (1988) Comparative analysis of the effect of a power station and of small mesh fisheries on the juvenile populations of smelt and flounder in the Loire Estuary - presentation of methods. J Fish Biol 33:243-244

Robin J.P (1991) Assessment of juvenile flounder catches at the Cordemais power station water intake in the Loire Estuary. Neth J Sea Res 27:317-323

This article was submitted to the editor
Schneider G, Behrends G (1994) Populatıon dynamics and the trophic role of Aurelia aurita medusae in the Kiel Bight and western Baltic. ICES J Mar Sci 51:359-367

Summers JK (1989) Simulating the indirect effects of power plant entrainment losses on an estuarine ecosystem. Ecol Model 49:31-47

Tlews K (1970) Synopsis of biological data on the common shrimp Crangon crangon (Linnaeus, 1758). FAO Flsh Rep 57:1167-1224

Turnpenny AWH (1983) Multiple regression analysis for forecasting critical fish influxes at power station intakes. $J$ Appl Ecol 20:22-42

Van den Brink FWB, Van der Velde G (1986) Observations on the population dynamics and distribution of the white prawn Palaemon longirostris $\mathrm{H}$. Milne Edwards, 1837 (Crustacea, Decapoda, Natantia) in the Netherlands, with special reference to its occurrence in the major rivers. Arch Hydrobiol 107:465-495

Van den Broek WLF (1979) A seasonal survey of fish populations in the lower Medway Estuary, Kent, based on power station screen samples. Estuar Coast Mar Sci 9:1-15

Van der Veer HW. Sadee CFM (1984) Seasonal occurrence of the ctenophore Pleurobrachia pileus in the western Dutch Wadden Sea. Mar Biol 79:219-227

Wheeler AC (1979) The tidal Thames. The history of a river and its fishes. Routledge and Kegan Paul, London

Manuscript first received: June 23, 1996

Revised version accepted: September 3, 1996 


\section{Erratum}

\section{Re: Attrill MJ, Thomas RM}

Mar Ecol Prog Ser 143: 25-36 (1996)

- On page 32 the lower panels of Figs. 9 and 10 were accidentally exchanged. The correct layout is given below.
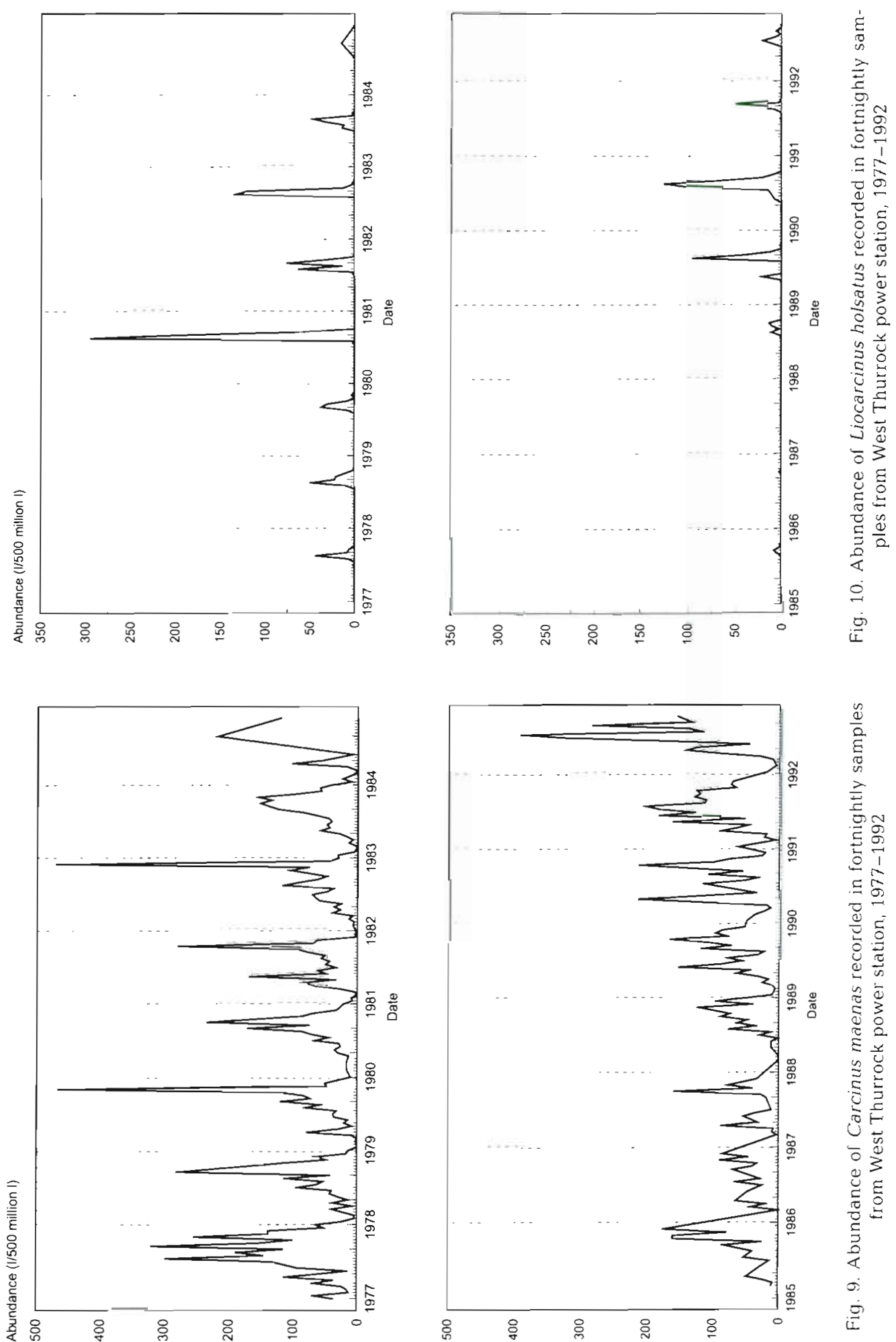